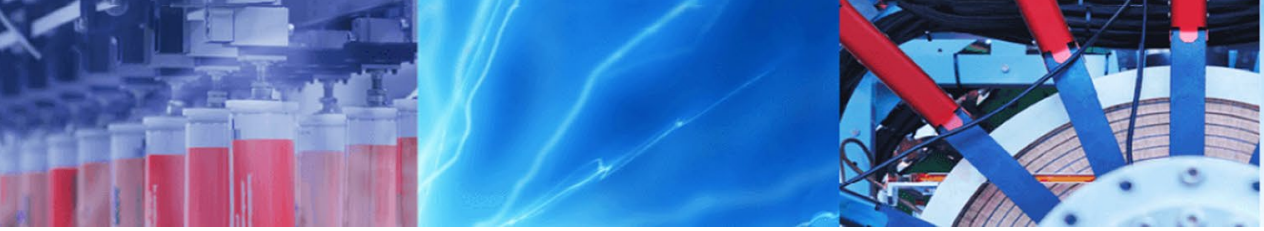

Research Article

\title{
Long-term trends in precipitation indices at eastern districts of Bangladesh
}

\author{
Zubayed Rakib ${ }^{1}$
}

(C) Springer Nature Switzerland AG 2019

\begin{abstract}
This study analyzed the trends of extreme daily rainfall indices over three meteorological stations located in the eastern region of Bangladesh from 1960 to 2000. The climate change-related indices included frequency-based indices: number of heavy rainfall days and consecutive dry and wet days, and intensity-based indices: annual wet-day rainfall total, daily and consecutive five-day maximum rainfall, very and extremely wet days and simple daily intensity index. The magnitude of trends in extreme rainfall indices time series was determined using the nonparametric Sen's slope estimator method, and the statistical significance of the trends was analyzed using the Mann-Kendall test. The rainfall trends exhibited regional patterns. Overall, results suggested an increase in annual rainfall over the study area; however, a tendency toward reduction of rainfall in the wet season was observed. Analysis of extreme rainfall indices demonstrated non-significant increase in frequency of heavy rainfall days, decrease in consecutive dry days and increase in consecutive wet days coupled with regional decline in daily and consecutive five-day maximum rainfall in the monsoon.
\end{abstract}

Keywords Rainfall · Climate change $\cdot$ Trend $\cdot$ Significant $\cdot$ Magnitude

\section{Introduction}

Precipitation is a primary component of the global hydrological cycle and a major climatic element directly affecting the availability of water resources [36]. It is widely accepted that one of the most visible consequences of global atmospheric warming has been the modification in water cycle [4], and the subsequent influence on agricultural and socioeconomic development of any region $[7,46]$. Consequently, precipitation irregularity, extreme precipitation events and concomitants of these climatic changes are of major concern in recent years.

Several studies have been carried out over different parts of the globe with regard to the changing rainfall patterns $[12,18,19,28,31,45]$. They indicate a small positive global trend, even though large areas have been instead characterized by negative trends. Investigations of climatic parameters were assessed to detect precipitation trends in Feidas et al. [13], Jain et al. [22], Chattopadhyay and Edwards [9], and Zhang et al. [55], which reveal that precipitation trends vary from coherent spatial patterns, in particular months or seasons, to highly regionalized patterns. Studies such as Vincent and Mekis [48], Alexander et al. [3], Vincent et al. [47], Donat et al. [11], Yazid and Humphries [54], Rahimi et al. [34], and Nashwan and Shahid [32] examined the trends and variations in indices representing extreme precipitation. They indicate significant trends for extreme rainfall days, rainfall intensity, and a tendency toward wetter conditions over various parts of the globe. Moreover, the extent of future rainfall change has also been estimated using different simulation techniques $[18,23,30]$. These studies project significant increase in rainfall extremes, dry spells, and reduction in precipitation in the wet season.

Variations in regional and local climate largely depend on regional and local features. As such, trends in regional climate may not always match with those on a global scale [37]. This warrants the need for assessment of climate

Zubayed Rakib, zubayed.rakib@gmail.com | 'Department of Civil Engineering, University of Utah, Salt Lake City, UT 84112, USA.

SN Applied Sciences (2019) 1:576 | https://doi.org/10.1007/s42452-019-0602-5 
variability on a smaller scale to improve our understanding of long-term regional climate trends. Regardless of the huge volume of climate change studies over different parts of the world, global pictures of changes in climate extremes typically show large areas with sparse data coverage [14], such as parts of South Asia. Rahman et al. [36] pointed out a major dimension of climate change for South Asia includes erratic and highly intensive precipitation events with large variability at monthly scale. Such abnormal precipitation characteristics can have adverse consequences at multi-dimensional scale on a country like Bangladesh. In reviewing relevant studies in Bangladesh, there is limited information about past climate change at the national level. In the past, studies were carried out on the annual and seasonal rainfall trends over Bangladesh [1, $37,39,42,43]$. These studies reported high rainfall variability, erratic seasonal patterns and declining rainfall trend over various parts of the country. Studies on the variability of extreme rainfall events in Bangladesh include Shahid [44] and Basher et al. [6]. These studies saw a decreasing trend in consecutive wet days and an increasing trend in consecutive dry days, particularly for the northern parts of Bangladesh. Ahmed and Alam [2], Islam [20], Rahman and Ferdousi [35] and Bhuyan et al. [8] performed analysis of rainfall projections and uncertainties from climate models for different regions over Bangladesh. Rahman et al. [36] demonstrated the spatial variations of an extreme rainfall indicator over Bangladesh using regional climate model projected results. Ara and Ostendorf [5] and Hossain and Paul [17] discussed on the food security and food policies and disaster mitigation measures in relation to rainfall events in Bangladesh. Despite the existing studies illustrating the rainfall variability and extremes over Bangladesh, additional research is required to better understand the nature and magnitude of the changes in extreme precipitation at regional scale.

In this paper, the rainfall data from four decades (1960-2000) in three districts located in eastern regions of Bangladesh were analyzed in order to evaluate the magnitude of the regional changes in extreme precipitation statistically. Specifically, the trends, variability and regional patterns of frequency-based and intensity-based extreme rainfall indices recommended by ETCCDI were assessed and analyzed at annual, seasonal and monthly scales.

\section{Materials and methods}

\subsection{Study area and data description}

Geographically, Bangladesh stands on the northern shoreline of the Bay of Bengal, extending between $20^{\circ} 34^{\prime}-26^{\circ} 38^{\prime} \mathrm{N}$ latitude and $88^{\circ} 01^{\prime}-92^{\circ} 41^{\prime} \mathrm{E}$ longitude.
The area has a tropical monsoon climate characterized by heavy seasonal rainfall, high temperatures, and high humidity [38]. In general, maximum summer temperatures range between 38 and $41^{\circ} \mathrm{C}$, while winter temperatures over most parts of the country vary between 16 and $20^{\circ} \mathrm{C}$ [39]. Rainfall total varies from $1400 \mathrm{~mm}$ in the west to more than $4300 \mathrm{~mm}$ in the east of the country, with $2300 \mathrm{~mm}$ being the country-wide average. Monsoon months June and July typically receive the most rainfall, $470 \mathrm{~mm}$ and $525 \mathrm{~mm}$, respectively, on average across the country. The average annual relative humidity ranges from $70.5 \%$ to $78.1 \%$ over the country. Land elevations of the northeast region vary mostly between 21 and $30 \mathrm{~m}$, while those at the southeast parts are mostly above $40 \mathrm{~m}$ [43].

In this paper, trend analysis has been performed for rainfall indices at Sylhet $\left(24.53^{\circ} \mathrm{N}, 91.52^{\circ} \mathrm{E}\right)$, Comilla $\left(23.27^{\circ} \mathrm{N}, 91.12^{\circ} \mathrm{E}\right)$ and Cox's Bazar $\left(21.43^{\circ} \mathrm{N}, 92.01^{\circ} \mathrm{E}\right)$ Districts located in the northeast, mid-east and southeast regions of the country for 1960-2000 time frame. Sylhet has a subtropical climate and lush highland terrain. The rainy season from April to October is hot and humid in this region with heavy showers and thunderstorms. Nearly $80 \%$ of the annual average rainfall of $4130 \mathrm{~mm}$ occurs between May and September. Located in the mid-east region of Bangladesh, Comilla has a tropical climate. In winter, there is much less rainfall in Comilla than in summer. The average annual rainfall is $2170 \mathrm{~mm}$. Cox's Bazar is located in the tropical monsoon southeast coastal region. The climate of Cox's Bazar is mostly characterized by high temperatures, heavy rainfall, excessive humidity and distinct seasonal variations. The average amount of rainfall remains at $3670 \mathrm{~mm}$. The selected districts are important from national agriculture and economic viewpoint. Sylhet and its surrounding areas are a traditional tea-growing region, which is heavily impacted by rainfall patterns. Comilla is the second-largest city of eastern Bangladesh and a hub of road communication for the eastern part of the country. Cox's Bazar is the district headquarters in southeastern Bangladesh. A mix of small-scale agriculture, aquaculture, and marine and inland fishing in this region play important roles in the national economy, all of which are influenced by regional rainfall. The 1960-2000 time frame, consistent with previous studies [16, 25, 27, 49, 56], was used for convenience of comparison and relevance of the frequency and trends of the rainfall and extreme rainfall indices with other parts of the globe.

Daily rainfall data were obtained from the Bangladesh Meteorological Department (BMD). To maintain data quality, a month was considered as having complete data if there was less than or equal to 5 missing days, and a year was considered complete if all months were complete according to above criteria $[38,40]$. Figure 1 shows the selected stations for analysis. 


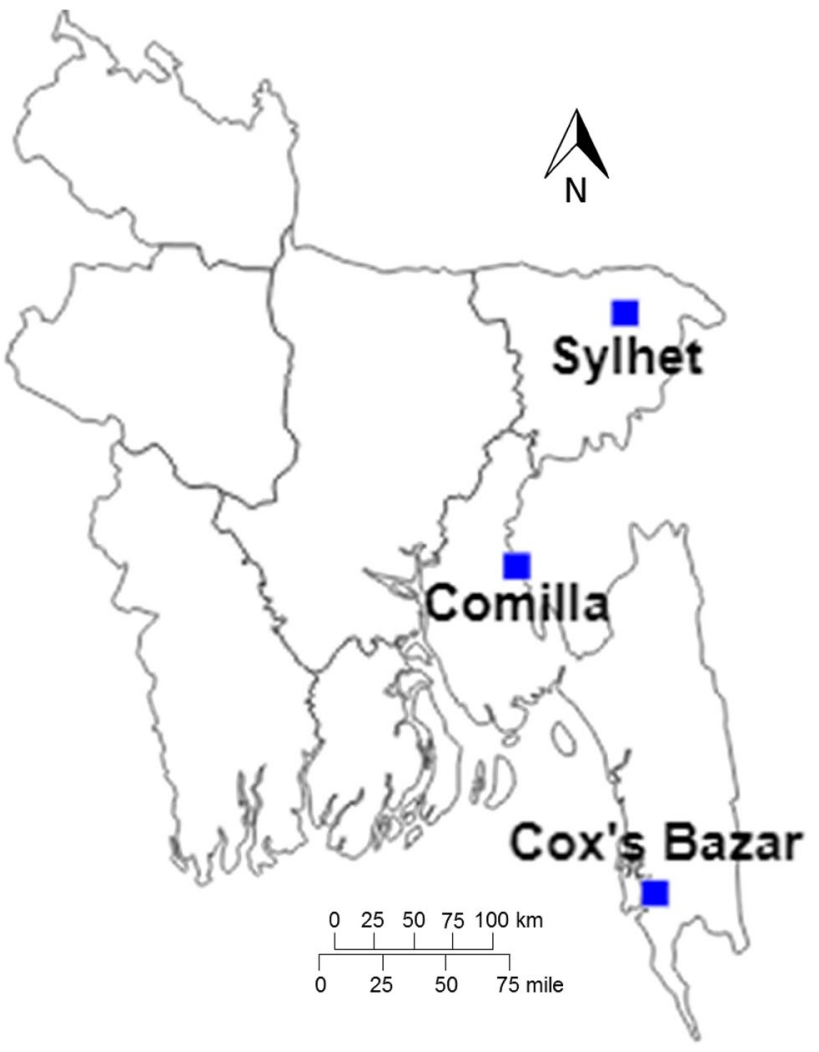

Fig. 1 Selected meteorological stations

\subsection{Definition of rainfall indices}

The joint CCI/CLIVAR/JCOMM Expert Team on Climate Change Detection and Indices (ETCCDI) has defined several climate change indices for the detection, measurement, and characterization of climate variability and change. Ten precipitation indices approved by the ETC$\mathrm{CDI}$ have been used for characterizing the precipitation trends at three districts located in the eastern region of
Bangladesh. These indices were categorized as frequencybased and intensity-based. The extreme precipitation indices are presented in Table 1. Frequency-based indices include the annual count of days when rainfall is greater than $10 \mathrm{~mm}$ and $20 \mathrm{~mm}$, consecutive dry days (CDD), and consecutive wet days (CWD), and the intensity-based indices consists of monthly maximum 1-day precipitation, monthly maximum consecutive 5 -day precipitation, annual total precipitation in wet days, and Simple Daily Intensity Index (SDII).

A day with minimum rainfall of $1 \mathrm{~mm}$ is considered as wet day. The CDD is calculated as the largest number of consecutive days where daily rainfall is less than $1 \mathrm{~mm}$, while the CWD is the largest number of consecutive days where rainfall is greater than $1 \mathrm{~mm}$. For the percentilebased indices, R95p and R99p, the 95th and the 99th percentile of the rainfall on wet days in the observation period (1960-2000) is obtained, and the total daily rainfall greater than the 95th and the 99th percentile value is calculated. The daily intensity, SDII, is the ratio of the total precipitation amount on wet days to the number of wet days.

\subsection{Data quality control}

Forty years of daily precipitation data (1960-2000) were used to calculate the precipitation indices. The precipitation series were tested first for homogeneity using the 'RHtests dlyPrcp' package, maintained by the Climate Research Division at Atmospheric Science and Technology Directorate of Canada. This software package can be used to detect and adjust for multiple change points (shifts) that could exist in a data series that may have first order autoregressive errors [52]. It is built on the principle of penalized maximal $t$ test [53] and the penalized maximal $F$ test [50,51]. Based on analysis, no significant change point was identified in the daily precipitation time series at Sylhet, Comilla and Cox's Bazar
Table 1 Extreme precipitation indices

\begin{tabular}{lll}
\hline Index & Definition & Unit \\
\hline $\begin{array}{l}\text { Frequency indices } \\
\text { R10mm }\end{array}$ & Annual count of days when rainfall $\geq 10 \mathrm{~mm}$ & days \\
R20mm & Annual count of days when rainfall $\geq 20 \mathrm{~mm}$ & days \\
CDD & Maximum number of consecutive days with rainfall $<1 \mathrm{~mm}$ & days \\
CWD & Maximum number of consecutive days with rainfall $\geq 1 \mathrm{~mm}$ & days \\
Intensity indices & Monthly maximum 1-day precipitation & \\
RX1day & Monthly maximum consecutive 5-day precipitation & $\mathrm{mm}$ \\
RX5day & Annual total rainfall when rainfall $>95$ th percentile & $\mathrm{mm}$ \\
R95p & Annual total rainfall when rainfall $>99$ th percentile & $\mathrm{mm}$ \\
R99p & Annual total precipitation in wet days & $\mathrm{mm}$ \\
PRCPTOT & Average precipitation amount on wet days & $\mathrm{mm}$ \\
SDII & & $\mathrm{mm} /$ day \\
\hline
\end{tabular}


stations. The time series tested was therefore considered to be homogeneous.

\subsection{Trend detection and characterization}

A trend is a significant change over time exhibited by a random variable, detectable by statistical parametric and nonparametric procedures [28]. For trend detection in the climatic variables time series, nonparametric statistical procedures were applied in this study. The magnitude of the trend in a time series was determined using a nonparametric method known as Sen's estimator [41], and the statistical significance of the trend was analyzed using the Mann-Kendall (MK) test $[24,29]$.

The MK test compares the relative magnitudes of data rather than data values themselves [15]. The benefit of this test is that the data do not need to conform any statistical distribution. In this test, each data value in the time series is compared with all subsequent values. The MK statistic, $S$, of the series $x$ is given by:

$S=\sum_{i=1}^{n-1} \sum_{j=i+1}^{n} \operatorname{sgn}\left(x_{j}-x_{i}\right)$

where sgn is the signum function. The variance associated with $S$ is calculated from:

$V(s)=\frac{n(n-1)(2 n+5)-\sum_{k=1}^{m} t_{k}\left(t_{k}-1\right)\left(2 t_{k}+5\right)}{18}$

where $m$ is the number of tied groups and $t_{k}$ is the number of data points in group $k$. In cases where the sample size $n>10$, the test statistic $Z(S)$ is calculated from:

$Z(S)= \begin{cases}\frac{S-1}{\sqrt{V(S)}}, & \text { if } S>0 \\ 0, & \text { if } S=0 \\ \frac{S+1}{\sqrt{V(S)}}, & \text { if } S<0\end{cases}$

Positive values of $Z(S)$ indicate increasing trends, while negative $Z(S)$ values reflect decreasing trends. Trends are considered significant if $|Z(S)|$ are greater than the standard normal deviate $Z_{1-\alpha / 2}$ for the desired value of $a$.

The Sen's approach was used in this study to quantify the significant linear trends in the time series. Widely used for determining the magnitude of trend in hydro-meteorological time series [9, 22, 43], Sen's slope has the advantage over the regression slope in the sense that it is not affected by gross data errors and outliers. The slope, $Q$, between any two values of a time series $x$ can be estimated from:

$Q=\frac{x_{k}-x_{j}}{k-j}, \quad k \neq j$

\section{SN Applied Sciences}

For a time series $x$ having $n$ observations, there are a possible $N=n(n-1) / 2$ values of $Q$ that can be calculated. According to Sen's method, the overall estimator of slope is the median of these $N$ values of $Q$. The overall slope estimator $Q^{*}$ is given by:

$Q^{*}= \begin{cases}Q_{(N+1) / 2}, & N \text { is odd } \\ \frac{Q_{N / 2}+Q_{(N+2) / 2}}{2}, & N \text { is even }\end{cases}$

The confidence interval of the slope is calculated from the same array of ordered slopes $Q_{i}$ using indexes $M_{1}$ and $M_{2}$ [9]. The lower and upper limits of the confidence interval are the $M_{1}$ th and $\left(M_{2}+1\right)$ th largest of the $N$-ordered slope estimates $Q_{i}$. Indices $M_{1}$ and $M_{2}$ are determined from:

$M_{1}=\left(N-C_{\alpha}\right) / 2$

$M_{2}=\left(N+C_{\alpha}\right) / 2$

where

$C_{\alpha}=Z_{1-\alpha / 2} \sqrt{\operatorname{Var}(S)}$

where $S$ is the MK test statistic, and $C_{\alpha}$ is the confidence interval. Using tabulated $Z$ values for cumulative normal distribution, the $95 \%$ confidence interval is calculated using $Z_{1-0.05 / 2}=1.96$. The confidence band of a time series depends on the sample size and variance of the data. A time series with very low variance and higher sample size may result in a narrow confidence interval. In general, the narrower the interval (at a given confidence level), the less uncertainty there is about the results.

\section{Results}

\subsection{Rainfall trends}

Annual total rainfall in the northeast region is highest among the country, ranging from 3040 to $5620 \mathrm{~mm}$, with an average of $4130 \mathrm{~mm}$ at the Sylhet station during 1960-2000. For the same time frame, the annual total rainfall at Comilla varied between 1240 and $3430 \mathrm{~mm}$, with a mean of $2170 \mathrm{~mm}$. The annual precipitation total ranged from a low of $1300 \mathrm{~mm}$ to a high of $5120 \mathrm{~mm}$ at the Cox's Bazar station located in the southeast region, with a mean of $3670 \mathrm{~mm}$ during 1960-2000. The annual rainfall amount in the mid-eastern region is relatively lower than the northeast and southeast regions. The standard deviation of annual rainfall at Sylhet, Comilla and Cox's Bazar stations was $635 \mathrm{~mm}, 434 \mathrm{~mm}$ and $758 \mathrm{~mm}$, respectively, indicating that rainfall at Cox's Bazar is slightly more variable than other two regions. Station-wise monthly and seasonal average rainfall quantities are presented in Tables 2 and 3 . 
Table 2 Monthly precipitation trend detection and characterization, 1960-2000

\begin{tabular}{|c|c|c|c|c|c|c|}
\hline \multirow[t]{2}{*}{ Month } & \multicolumn{2}{|l|}{ Sylhet } & \multicolumn{2}{|l|}{ Comilla } & \multicolumn{2}{|l|}{ Cox's Bazar } \\
\hline & Mean $(\mathrm{mm})$ & $\begin{array}{l}\text { Sen's } Q \\
\text { (mm/decade) }\end{array}$ & Mean $(\mathrm{mm})$ & $\begin{array}{l}\text { Sen's } Q \\
\text { (mm/decade) }\end{array}$ & Mean (mm) & $\begin{array}{l}\text { Sen's } Q \\
\text { (mm/decade) }\end{array}$ \\
\hline January & 10 & 0.00 & 7 & 0.00 & 6 & 0.00 \\
\hline February & 49 & 0.00 & 21 & $4.21^{+}$ & 16 & $0.56^{*}$ \\
\hline March & 128 & $25.37^{*}$ & 56 & $16.43^{*}$ & 31 & 1.14 \\
\hline April & 344 & 18.87 & 148 & 4.00 & 95 & 16.13 \\
\hline May & 549 & 23.25 & 284 & $45.52^{*}$ & 283 & 27.19 \\
\hline June & 814 & -16.48 & 397 & $-63.40^{* *}$ & 848 & -15.99 \\
\hline July & 820 & 8.18 & 446 & -40.91 & 980 & -11.83 \\
\hline August & 632 & 4.13 & 344 & -32.50 & 724 & -32.21 \\
\hline September & 526 & 49.05 & 245 & -13.57 & 353 & $38.26^{+}$ \\
\hline October & 218 & 3.52 & 169 & -3.79 & 240 & -28.99 \\
\hline November & 29 & 0.00 & 42 & 0.00 & 76 & 5.49 \\
\hline December & 9 & 0.00 & 10 & 0.00 & 14 & 0.00 \\
\hline
\end{tabular}

Significance: ${ }^{* *}$ for $p<0.01,{ }^{*}$ for $p<0.05,+$ for $p<0.1$

\begin{tabular}{|c|c|c|c|c|c|c|}
\hline \multirow[t]{2}{*}{ Month } & \multicolumn{2}{|l|}{ Sylhet } & \multicolumn{2}{|l|}{ Comilla } & \multicolumn{2}{|l|}{ Cox's Bazar } \\
\hline & Mean (mm) & $\begin{array}{l}\text { Sen's } Q \\
\text { (mm/decade) }\end{array}$ & Mean (mm) & $\begin{array}{l}\text { Sen's } Q \\
\text { (mm/decade) }\end{array}$ & Mean $(\mathrm{mm})$ & $\begin{array}{l}\text { Sen's } Q \\
\text { (mm/decade) }\end{array}$ \\
\hline Pre-monsoon & 1021 & $85.06^{*}$ & 488 & $68.94^{*}$ & 409 & $60.00^{+}$ \\
\hline Monsoon & 3010 & 54.07 & 1601 & $-141.43^{*}$ & 3145 & $-51.33^{*}$ \\
\hline Dry & 97 & 0.84 & 80 & 6.11 & 113 & 20.63 \\
\hline
\end{tabular}

Significance: * for $p<0.05,+$ for $p<0.1$
Table 3 Seasonal precipitation trend detection and characterization, 1960-2000 station. The trend during March was found to be statistically significant at $p$ value 0.05 . On the other hand, the monthly variability in rainfall seems to be higher at the Cox's Bazar station. Negative trends are observed during June, July, August, and October months. These months typically receive most of the rainfall at Cox's Bazar station, which tends to be declining. In contrast, increasing trends during February and September at this station are statistically significant. Declining rainfall trends are observed from June to October at Comilla station, the trend during June being statistically significant at $99 \%$ confidence level. On the contrary, the trends during February, March and May at this station are found to be positive, all of which are statistically significant.

Examining the rainfall trends on the seasonal scale reveals the extremity of the climate condition, as the temporal distribution of rainfall seems to be shifting from monsoon (June-October) to pre-monsoon (March-May) season, particularly in the mid-east and southeast regions of the country. The increasing trend in annual rainfall at Sylhet is reflected in the seasonal trends. All seasons exhibited positive rainfall trends at this station, the trend 

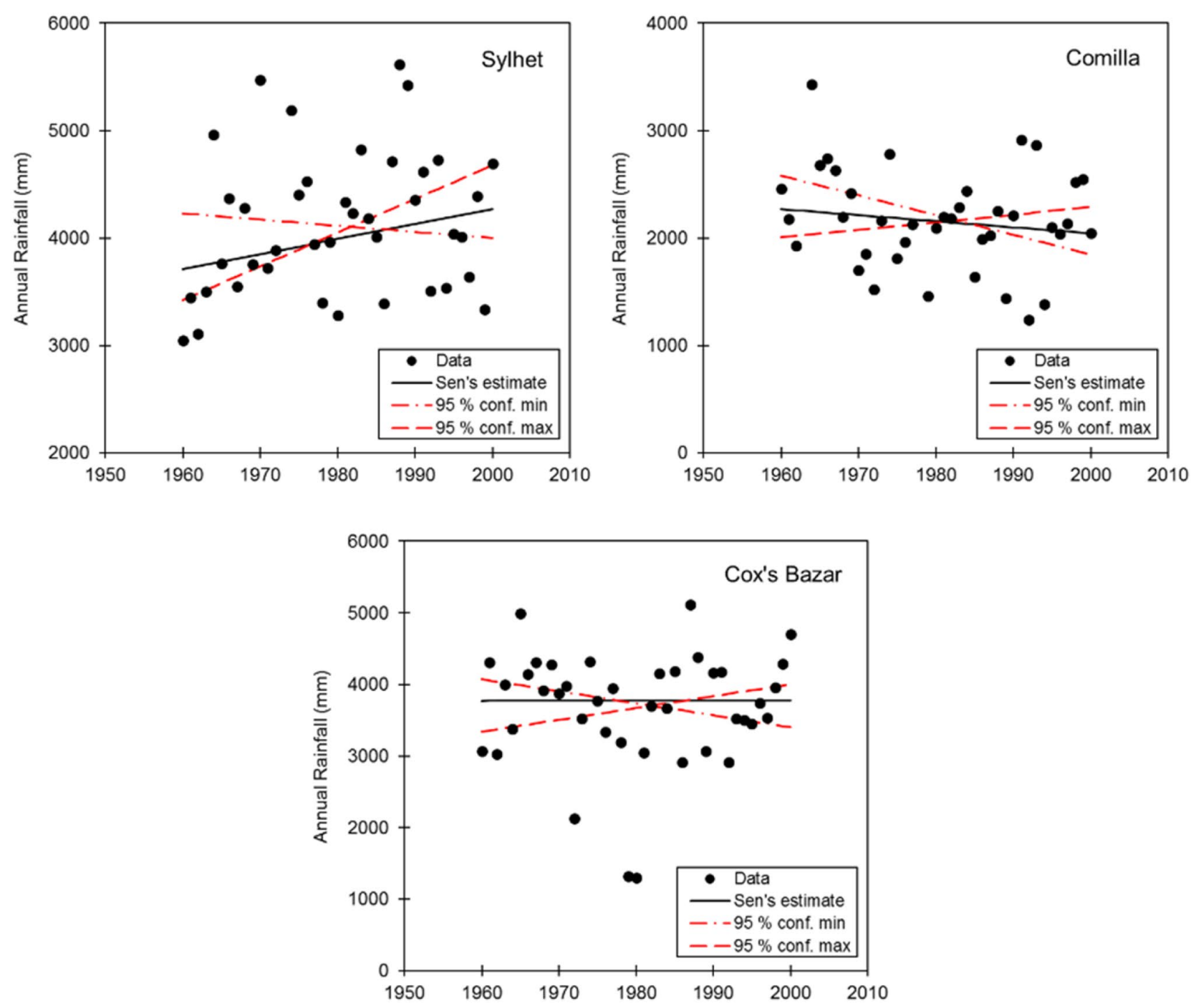

Fig. 2 Trend analysis of annual precipitation at selected stations, 1960-2000

during pre-monsoon being statistically significant at $95 \%$ confidence level. However, at the Comilla and Cox's Bazar regions, the monsoon rainfall sees statistically decreasing trends at $95 \%$ confidence level. On the other hand, pre-monsoon rainfall has increased significantly at both stations at $95 \%$ confidence level. The high magnitude of decreasing monsoon rainfall $(-141.43 \mathrm{~mm} /$ decade) at Comilla region is perhaps contributing to the decreasing trend in annual rainfall total. At Cox's Bazar, the changes during monsoon and pre-monsoon seem to offset each other. At Sylhet and Cox's Bazar stations, rainfall in September is experiencing the most increase due to the temporal and seasonal shift.

Overall, increasing trend in annual total rainfall in the eastern regions of Bangladesh is consistent with previous studies $[26,37,43]$, who found an increasing trend in rainfall over Bangladesh after 1960. As expected, previous studies observed highly regionalized rainfall patterns in the neighboring areas. The rainfall trends, however, are comparable to the magnitude of the trends obtained in this study, such as -3.01 to $75.4 \mathrm{~mm} /$ decade over northeast India [22], -24.1 to $49.3 \mathrm{~mm} /$ decade over western and southeastern India [21], and -62.9 to $27.5 \mathrm{~mm} /$ decade over Nepal [33]. Jain and Kumar [21] observed increasing trend in annual rainy days coupled with decrease in annual rainfall total over eastern regions of India, which agrees with the findings for Comilla region in this study. They also reported a decrease in long-term monsoon rainfall over Assam and Meghalaya states of India, which are located at close proximity to the study area in this paper. Based on seasonal analysis, Jain et al. [22] and Deshpande et al. [10] also observed negative trends of -30.3 to $-2.0 \mathrm{~mm} /$ 
decade in monsoon rainfall over major river basins of India. Basher et al. [6] reported decreasing trend in the monsoon seasonal total rainfall over northeast Bangladesh. Shahid [43] detected a significant increase in pre-monsoon rainfall over Bangladesh. The above findings are consistent with the annual and seasonal magnitudes and trend directions of rainfall in the analyzed eastern districts of Bangladesh.

\subsection{Rainfall indices trends}

Figures 3,4 and 5 provide detailed illustration of the precipitation indices, along with the calculated trend slope and $95 \%$ confidence limits on the slope for Sylhet, Comilla and Cox's Bazar stations during 1960-2000. Magnitude and statistical significance of these trends are tabulated in Table 4. Negative sign of the slope of a trend line indicates decline, while positive sign indicates a rise.

\subsubsection{Frequency indices}

Frequency indices comprise R10mm, R20mm, consecutive dry days (CDD), and consecutive wet days (CWD). Yazid and Humphries [54] designated R10 $10 \mathrm{~m}$ and R20mm as number of days with heavy rainfall and very heavy rainfall, respectively. The annual frequency of the heavy rainfall day (R10mm) index has a range of 56-102 days each year. Among the three stations, the lowest number of heavy rainfall days occurred at Comilla, while the Sylhet had the highest number of heavy rainfall days. All the stations exhibited non-significant positive trends of order $0.36-1.82$ days/decade.

The annual frequency of very heavy rainfall day (R20mm) was found to be lowest at Comilla station (35 days/year). Cox's Bazar and Sylhet had 55 days/year and 67 days/year having very heavy rainfall. Comilla exhibited a negative trend in the $\mathrm{R} 20 \mathrm{~mm}$; however, the trend was not statistically significant. On the other hand, Cox's Bazar and Sylhet displayed non-significant positive trends for $\mathrm{R} 20 \mathrm{~mm}$. The fact that $\mathrm{R} 10 \mathrm{~mm}$ showed a rising trend, but a falling R20 mm trend at Comilla illustrates a case of extreme climate condition. Decrease in number of days with very heavy rainfall $(\geq 20 \mathrm{~mm})$ is perhaps contributing to the declining annual rainfall trend at this station.

The consecutive dry days (CDD) index in the eastern region of Bangladesh ranged between 58 and 72 days each year. Sylhet station displayed the least frequency for CDD. All three stations showed negative CDD trend. Among them, the negative trend at Cox's Bazar was statistically significant at $95 \%$ confidence level.

The regional pattern of the consecutive wet days (CWD) index showed a range of 11-29 days each year in the selected districts. All stations were found to exhibit positive trends for CWD of order 0.59-0.95 days/decade; however, these trends were not statistically significant. A declining CDD trend and an increasing CWD trend at Comilla region, combined with its declining annual rainfall trend, reveal that the quantity of daily rainfall has decreased in the area although more days are seeing rainfall events. The contributing factor could be the decreasing pattern of monsoon rainfall in the region.

\subsubsection{Intensity indices}

Intensity indices comprised of PRCPTOT, R95p, R99p, RX1day, RX5day, and SDII. The mean climatology of daily maximum rainfall (RX1day) in the area has a range from 145 to $208 \mathrm{~mm}$ as shown in Table 4. Mann-Kendall and Sen's Slope trend analysis revealed negative RX1day trends at Comilla and Cox's Bazar stations, while Sylhet displayed a positive slope for RX1day. However, none of these trends were statistically significant.

The mean climatology of the 5-day maximum rainfall (RX5day) was similar in pattern as RX1day. The northeastern and southeastern regions have a higher intensity of five-day maximum rainfall ranging from 444 to $518 \mathrm{~mm}$, while mid-eastern area has a lower intensity of five-day maximum rainfall of $287 \mathrm{~mm}$. Like RX1day trends, RX5day trends at Comilla and Cox's Bazar locations were negative. The negative trend of $21.94 \mathrm{~mm} /$ decade at Cox's Bazar was statistically significant at $90 \%$ confidence level.

The mean climatology of the annual wet-day rainfall total (PRCPTOT) varies from $2165 \mathrm{~mm}$ at Comilla to $4174 \mathrm{~mm}$ at Sylhet. Comilla station displayed non-significant negative PRCPTOT trend of order $40.57 \mathrm{~mm} /$ decade. The trends at Sylhet and Cox's Bazar were positive; however, the magnitude of the trends varied from as low as $1.67 \mathrm{~mm} /$ decade at Cox's Bazar to as high as $88.75 \mathrm{~mm} /$ decade at Sylhet. None of these trends were found to be statistically significant.

The mean climatology of very wet days (R95p) and extremely wet days (R99p) ranged from 551 to $1035 \mathrm{~mm}$ and 171 to $336 \mathrm{~mm}$, respectively. The resulting patterns of both R95p and R99p indices were similar. Mann-Kendall and Sen's Slope trend analysis revealed statistically significant negative R95 $p$ trend ( $p$ value 0.05 ) of order $13.09 \mathrm{~mm} /$ year at Cox's Bazar station. The trend at Comilla was $-38.67 \mathrm{~mm} /$ decade, although not statistically significant. On the contrary, Sylhet station exhibited non-significant positive R95p trend. R99p trend at Sylhet was also positive, however statistically insignificant.

The Simple Daily Intensity Index (SDII) is an index representing extreme precipitation to evaluate the intensity of rainfall. It depends on the annual rainfall amounts and annual rainy days, meaning trends of both annual rainfall amount and annual rainy days have impacts on the trend of SDII. The SDII ranges from $20 \mathrm{~mm} /$ day at Comilla to 

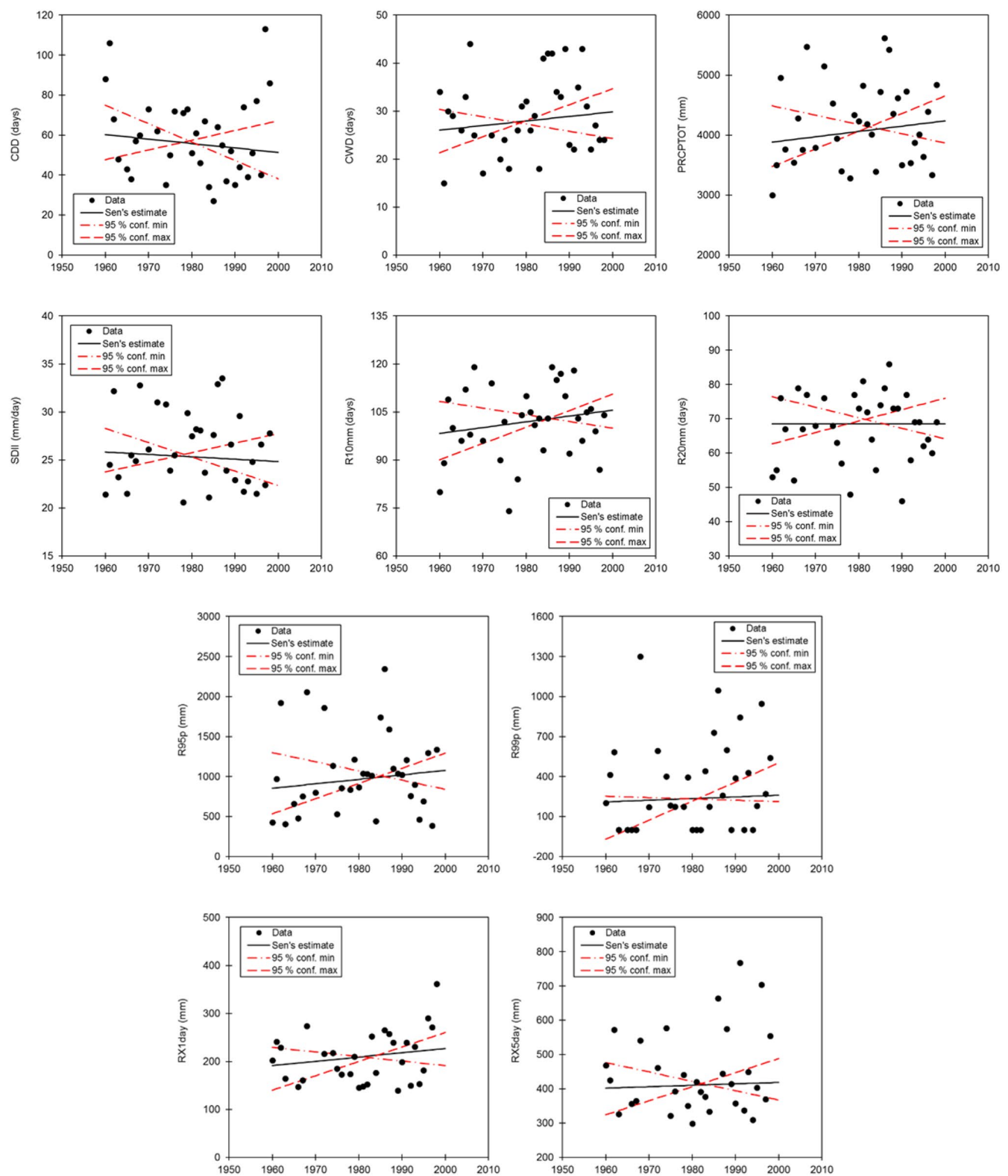

Fig. 3 Precipitation indices trends at Sylhet station, 1960-2000. Solid straight lines indicate the linear trend, and dashed straight lines indicate the $95 \%$ confidence limits estimated with Sen's Slope estimator method 

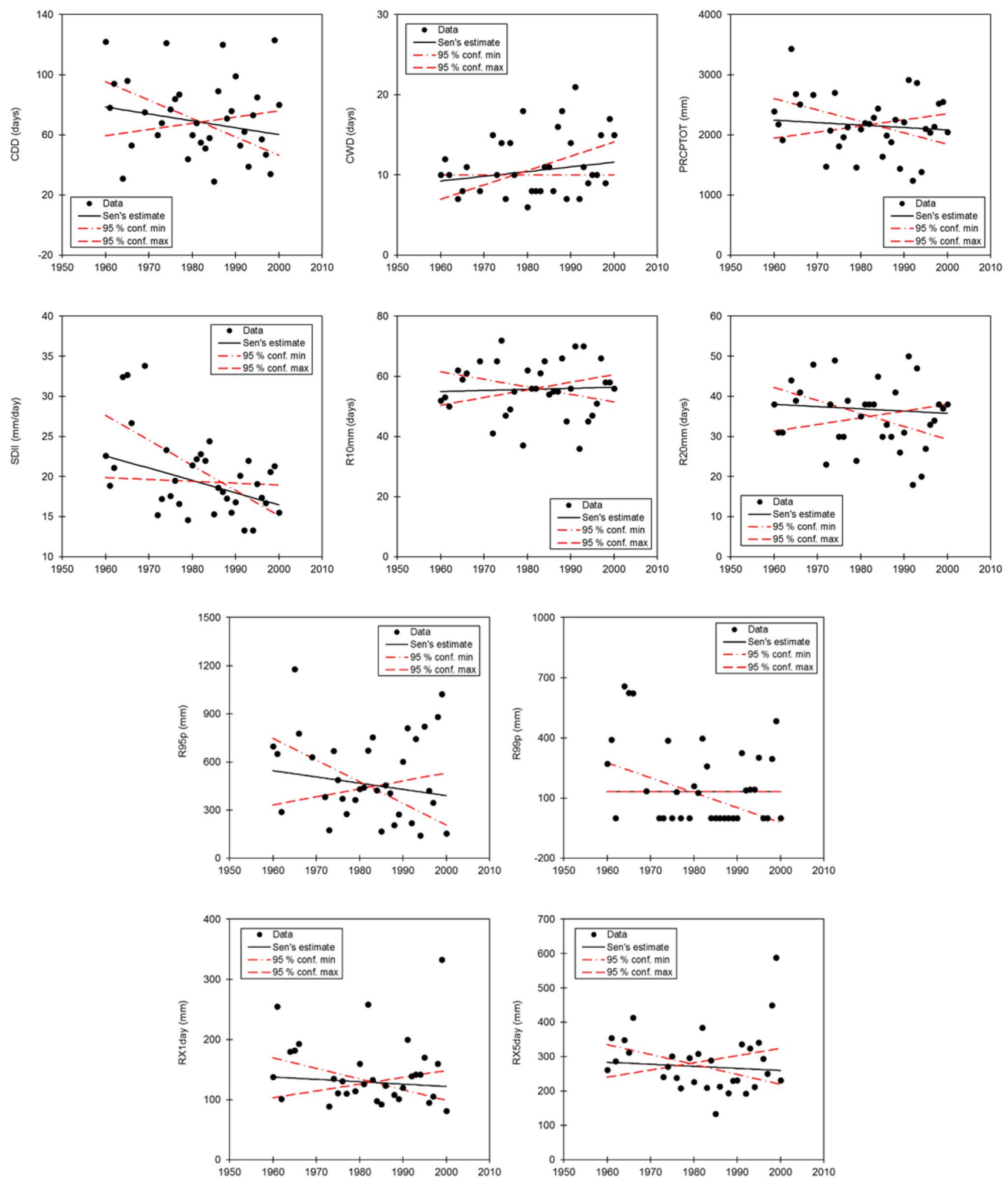

Fig. 4 Precipitation indices trends at Comilla station, 1960-2000. Solid straight lines indicate the linear trend, and dashed straight lines indicate the $95 \%$ confidence limits estimated with Sen's Slope estimator method 

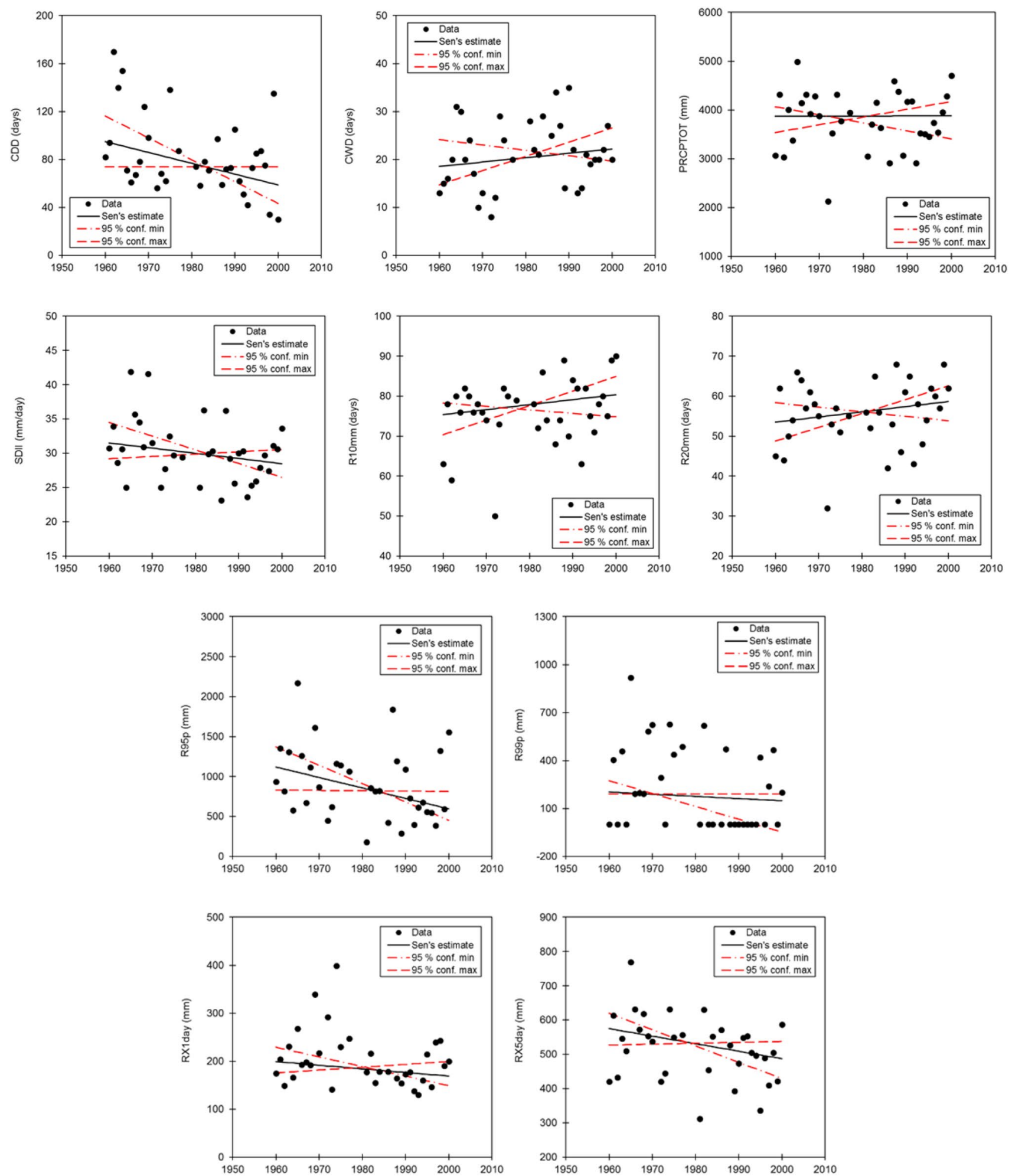

Fig. 5 Precipitation indices trends at Cox's Bazar station, 1960-2000. Solid straight lines indicate the linear trend, and dashed straight lines indicate the $95 \%$ confidence limits estimated with Sen's Slope estimator method

$30 \mathrm{~mm} /$ day at Cox's Bazar. Based on the SDIl value guide, the intensity of rainfall at Comilla, Sylhet and Cox's Bazar can be categorized as 'high intensity' (20-25 mm/day), 'strong intensity' (25-30 mm/day), and 'very strong intensity' (over $30 \mathrm{~mm} /$ day), respectively. Such highly intensive rainfall has high erosion-potentials that can lead to 
Table 4 Precipitation indices trend detection and characterization, 1960-2000

\begin{tabular}{|c|c|c|c|c|c|c|}
\hline \multirow[t]{2}{*}{ Index } & \multicolumn{2}{|l|}{ Sylhet } & \multicolumn{2}{|l|}{ Comilla } & \multicolumn{2}{|c|}{ Cox's Bazar } \\
\hline & Mean & Sen's $Q$ & Mean & Sen's $Q$ & Mean & Sen's $Q$ \\
\hline \multicolumn{7}{|l|}{ Frequency indices } \\
\hline R10mm (days) & 101.6 & 1.82 & 55.9 & 0.36 & 76.2 & 1.25 \\
\hline R20mm (days) & 67.3 & 0.00 & 35.2 & -0.56 & 55.4 & 1.29 \\
\hline CDD (days) & 58.7 & -2.22 & 71.9 & -4.57 & 83.2 & $-9.05^{*}$ \\
\hline CWD (days) & 29.1 & 0.95 & 11.2 & 0.59 & 21.0 & 0.91 \\
\hline \multicolumn{7}{|l|}{ Intensity indices } \\
\hline PRCPTOT (mm) & 4174.2 & 88.75 & 2165.3 & -40.57 & 3784.1 & 1.67 \\
\hline R95p (mm) & 1034.7 & 55.77 & 551.3 & -38.67 & 914.4 & $-130.91 *$ \\
\hline R99p (mm) & 336.4 & 12.27 & 171.1 & 0.00 & 223.8 & 0.00 \\
\hline RX1day (mm) & 207.9 & 8.82 & 144.5 & -3.96 & 202.2 & -7.58 \\
\hline RX5day (mm) & 444.3 & 4.19 & 286.6 & -5.94 & 516.7 & $-21.94^{+}$ \\
\hline SDII (mm/day) & 26.1 & -0.25 & 20.2 & $-1.53^{*}$ & 30.3 & -0.76 \\
\hline
\end{tabular}

Sen's slope estimates are per decade

Significance: * for $p<0.05,+$ for $p<0.1$ long-term flooding events. Trends analysis of SDII displays decreasing trends at all stations. Of these trends, Comilla has the highest magnitude of $-1.53 \mathrm{~mm} /$ day per decade, which is statistically significant at $95 \%$ confidence level. The decreasing annual rainfall is perhaps responsible for the significant negative SDII trend at Comilla. For the other two locations, decrease in SDII suggests to the decrease in annual rainy days.

The RX1day and RX5day indices were further analyzed at monthly and seasonal scale. Tables 5 and 6 present the results of Mann-Kendall trend test and Sen's Slope estimator test for the monthly and seasonal RX1day and
RX5day indices during 1960-2000 at the selected stations in the eastern region of Bangladesh. Pattern of the monthly RX1day and RX5day trends agrees well with the monthly precipitation trends shown previously in Table 2 . Both RX1day and RX5day showed decreasing trends during monsoon months (June-October) at Comilla station. RX1day trend in June at Comilla was statistically significant at $95 \%$ confidence level. At Cox's Bazar, monsoon months, except for September, showed declining trends for both RX1day and RX5day indices. However, these trends were not statistically significant. At Sylhet station, daily maximum rainfall ( $R X 1$ day) displayed a non-significant negative
Table 5 Monthly and seasonal $\mathrm{RX} 1$ day $(\mathrm{mm})$ trend detection, 1960-2000

\begin{tabular}{|c|c|c|c|c|c|c|}
\hline \multirow[t]{2}{*}{ Month/season } & \multicolumn{2}{|l|}{ Sylhet } & \multicolumn{2}{|c|}{ Comilla } & \multicolumn{2}{|c|}{ Cox's Bazar } \\
\hline & MK-Z & Sen's $Q$ & MK-Z & Sen's $Q$ & MK-Z & Sen's $Q$ \\
\hline January & 0.55 & 0.00 & 0.52 & 0.00 & 0.96 & 0.00 \\
\hline February & -0.67 & -1.54 & 1.24 & 1.61 & 2.01 & $0.33^{*}$ \\
\hline March & 0.79 & 3.33 & 1.57 & 5.10 & 1.40 & 0.64 \\
\hline April & 0.70 & 4.00 & 0.10 & 0.36 & 0.76 & 3.16 \\
\hline May & -0.01 & 0.00 & -0.06 & -0.42 & 0.87 & 7.35 \\
\hline June & -0.54 & -4.44 & -2.04 & $-10.98^{*}$ & -0.90 & -6.86 \\
\hline July & 1.41 & 10.38 & -0.70 & -3.75 & -0.14 & -0.80 \\
\hline August & 0.10 & 0.49 & -0.79 & -4.78 & -1.64 & -11.50 \\
\hline September & 0.30 & 3.10 & -0.10 & -0.88 & 1.71 & $10.62^{+}$ \\
\hline October & -0.12 & -0.55 & -0.63 & -4.14 & -2.07 & $-14.48^{*}$ \\
\hline November & -0.04 & 0.00 & 0.12 & 0.00 & 1.13 & 4.03 \\
\hline December & 1.01 & 0.00 & 0.59 & 0.00 & 1.01 & 0.00 \\
\hline Dry & 0.97 & 4.11 & 1.13 & 5.00 & 1.48 & 10.94 \\
\hline Pre-monsoon & 1.99 & $28.90^{*}$ & 0.93 & 10.55 & 1.60 & 14.79 \\
\hline Monsoon & 1.25 & 22.09 & -0.45 & -10.93 & -1.76 & $-30.00^{+}$ \\
\hline
\end{tabular}

Sen's slope estimates are per decade

Significance: * for $p<0.05,+$ for $p<0.1$ 
Table 6 Monthly and seasonal RX5day $(\mathrm{mm})$ trend detection, 1960-2000

\begin{tabular}{|c|c|c|c|c|c|c|}
\hline \multirow[t]{2}{*}{ Month/Season } & \multicolumn{2}{|l|}{ Sylhet } & \multicolumn{2}{|l|}{ Comilla } & \multicolumn{2}{|c|}{ Cox's Bazar } \\
\hline & MK-Z & Sen's $Q$ & MK-Z & Sen's $Q$ & MK-Z & Sen's $Q$ \\
\hline January & 0.51 & 0.00 & 0.53 & 0.00 & 0.86 & 0.00 \\
\hline February & -0.34 & -0.83 & 1.30 & 2.07 & 1.94 & $0.40^{+}$ \\
\hline March & 0.86 & 4.06 & 1.59 & 10.00 & 1.01 & 0.48 \\
\hline April & 0.77 & 7.65 & 0.78 & 7.20 & 1.42 & 10.91 \\
\hline May & 0.13 & 2.50 & 0.97 & 12.22 & 1.64 & 13.79 \\
\hline June & -1.40 & -17.50 & -1.57 & -20.00 & -0.66 & -16.11 \\
\hline July & 0.77 & 16.74 & -0.81 & -12.86 & -1.41 & -27.75 \\
\hline August & 0.26 & 3.64 & -1.19 & -11.25 & -0.55 & -6.99 \\
\hline September & 0.24 & 4.81 & 0.08 & 0.32 & 0.92 & 11.55 \\
\hline October & 0.56 & 6.33 & -0.36 & -3.33 & -1.64 & -23.24 \\
\hline November & 0.70 & 1.31 & 0.42 & 0.45 & 1.05 & 7.93 \\
\hline December & 0.64 & 0.00 & 0.38 & 0.00 & 0.75 & 0.00 \\
\hline Dry & 1.28 & 10.66 & 1.57 & 10.87 & 1.46 & 17.28 \\
\hline Pre-monsoon & 1.66 & $48.74^{+}$ & 2.05 & $37.64^{*}$ & 1.88 & $30.84^{+}$ \\
\hline Monsoon & 0.79 & 25.98 & -0.92 & -27.76 & -1.54 & -72.73 \\
\hline
\end{tabular}

Sen's slope estimates are per decade

Significance: * for $p<0.05,+$ for $p<0.1$ trend during February, June and October, while the 5-day maximum rainfall (RX5day) exhibited non-significant negative trends during February and June. The positive RX1day and RX5day trends in February at Cox's Bazar station were statistically significant at $95 \%$ and $90 \%$ confidence levels. This is consistent with the statistically significant positive trend of monthly precipitation at this station. Seasonal analysis shows that both RX1day and RX5day during monsoon are decreasing at Comilla and Cox's Bazar regions, the RX1day trend at Cox's Bazar being statistically significant at $90 \%$ confidence level, while pre-monsoon season exhibited positive trends for both indices at these stations. Among them, RX5day trends were statistically significant. The increasing trends of RX1day and RX5day during all seasons at Sylhet are consistent with its overall increasing annual rainfall trend. Analysis of the daily maximum rainfall (RX1day) and 5-day maximum rainfall (RX5day) indices reaffirms that the temporal distribution of monthly rainfall appears to be shifting from monsoon (June-October) to pre-monsoon (March-May) season, particularly in the mideast and southeast regions of Bangladesh.

Overall, the trends and variability of rainfall extremes over eastern Bangladesh agree with those of neighboring regions. For example, Yazid and Humphries [54] observed trends of -8.5 to 11.2 days/decade for CDD, -14.9 to 11.6 days/decade for CWD, -7.4 to 5.4 days/decade for $\mathrm{R} 10 \mathrm{~mm},-4.5$ to 2.9 days/decade for R20mm, -6.7 to $1.1 \mathrm{~mm} /$ decade for RX1 day, -13.9 to $22.3 \mathrm{~mm} /$ decade for RX5day, and -0.7 to $0.9 \mathrm{~mm} /$ day per decade for SDII indices over Indochina Peninsula countries (Vietnam, Thailand, Myanmar, Cambodia, Laos, parts of Malaysia, China,
Bangladesh, and India). Basher et al. [6] reported trends of -1.9 to 2.0 days/decade for CDD, -3.3 to 0.4 days/decade for CWD, -76.4 to $43.2 \mathrm{~mm} /$ decade for PRCPTOT, -11.7 to $2.5 \mathrm{~mm} /$ decade for RX1 day, -25.4 to $-2.7 \mathrm{~mm} /$ decade for RX5day, and -2.4 to $1.5 \mathrm{~mm} /$ day per decade for SDIl over northeastern region of Bangladesh. Deshpande et al. [10] observed trend of -0.3 to 0.5 days/decade for heavy rainfall days (R10mm) over major river basins of India. Rahimi et al. [34] reported trends of -12.4 to $2.5 \mathrm{~mm} /$ decade for RX1day, -5.7 to $4.4 \mathrm{~mm} /$ decade for RX5day, -1.4 to $0.5 \mathrm{~mm} /$ day per decade for SDII, -1.5 to 0.5 days/decade for R $10 \mathrm{~mm},-0.4$ to 0.7 days/decade for R20mm, -5.5 to 1.8 days/decade for CDD, -0.8 to 4.3 days/decade for CWD, -22.5 to $16.2 \mathrm{~mm} /$ decade for R95p, -23.8 to $12.2 \mathrm{~mm} / \mathrm{dec}$ ade for R99p, and -28.2 to $62.8 \mathrm{~mm} /$ decade for PRCPTOT indices over different parts of Iran.

\section{Discussion}

Results of Mann-Kendall trend test showed that average annual rainfall at Sylhet (northeast) and Cox's Bazar (southeast) areas has increased over time and has decreased at Comilla (mid-east) region. However, these trends were not significant. Although statistically significant positive trends were obtained for some months, a tendency toward reduction of rainfall in the wet monsoon season was observed. More importantly, the temporal distribution of rainfall patterns appeared to become more variable in the monsoon season. Historically, these months have received most of the annual rainfall in this region. As monsoon rainfall 
becomes more variable, local crops will begin to experience failure, and systemic changes in agricultural resource allocation and planning will be required [39]. The increase in daily temperatures may be responsible for the decrease in rainfall during the monsoon [40]. The rainfall variability in the southeastern hilly region during the early post-monsoon may be associated with the depressions or cyclone rain effects, which have been increasing in recent decades making the rainfall highly variable [37].

Analysis of trends in the extreme rainfall indices exhibited highly regional patterns. Frequency of heavy rainfall days demonstrated statistically non-significant increasing trends at Sylhet and Cox's Bazar, but a non-significant negative trend at Comilla. This may perhaps be contributing to the decreasing annual rainfall pattern at Comilla. Consecutive dry days exhibited negative trends, while consecutive wet days displayed positive trends at all stations. The trends of intensity-based indices were found to be rather regional in nature. For example, the wet days, daily maximum rainfall and consecutive 5 -day maximum rainfall trends were negative at Comilla and Cox's Bazar, but positive at Sylhet. Analysis of the daily maximum and 5-day maximum rainfall indices at monthly scale indicated a tendency toward reduction in monsoon rainfall. The Simple Daily Intensity Index (SDII) trends were negative across all stations.

Despite future uncertainties, trend analysis of extreme rainfall indices in the current study indicates that the rainfall pattern in the eastern regions of Bangladesh will become more variable. Rainfall is a vital part of the hydrologic cycle, and therefore its quantity, frequency and variability will affect the water resources, runoff, streamflows, soil moisture and groundwater recharge [22]. These changes will subsequently have impact on agriculture, food supply, irrigation and hydropower in the area of concern. For example, the monsoon floods are necessary for fertilizing the paddy fields and replenishing fish stocks in the haor lakes [6]. Thus, the declining trend of monsoon rainfall detected for the eastern districts of Bangladesh can affect paddy and fish production in this region. The increasing trends obtained for the daily maximum and 5-day maximum rainfall in the pre-monsoon, although statistically non-significant, may have implications for the flash flooding and long-term riverine flooding. The amount and distribution of total rainfall in wet days (PRCPTOT), especially during the pre-monsoon, influence the water levels in the seasonal haor lakes. Subsequently, the increasing trend of pre-monsoon rainfall and decreasing trend of consecutive dry days in the eastern regions of the country may help to increase soil moisture contents as well as Boro rice productivity [6]. This can also reduce the pressure on groundwater for irrigation in the areas. Similarly, reduction of winter rainfall can potentially impact production of winter crops such as wheat, vegetables and potatoes [33]. The Simple Daily Intensity Index (SDII) trends have implications for erosion-potentials that can lead to long-term flooding.

\section{Conclusion}

In this paper, rainfall data over a 40-year period (1960-2000) from three meteorological stations located in the eastern parts of Bangladesh were analyzed to evaluate the magnitude of regional changes in rainfall and extreme rainfall temporally. Analysis of extreme rainfall at annual, seasonal and monthly scales was based on frequencybased and intensity-based indices recommended by ETCCDI. The magnitude of trends of these rainfall indices was determined using the nonparametric Sen's slope estimator method, while the statistical significance of the trends were analyzed using the Mann-Kendall test. The rainfall trends exhibited regional patterns at monthly scale. Although results suggested an overall increase in annual rainfall over the region of concern, a tendency toward reduction of rainfall in the wet season was observed. The annual rainfall patterns were consistent with previous studies. Frequency-based indices displayed statistically non-significant increase in heavy rainfall days, decrease in consecutive dry days and increase in consecutive wet days. Regional decline in intensity-based indices such as daily and consecutive 5 -day maximum rainfall was observed in the monsoon season. Overall, the magnitudes of trends and variability of rainfall extremes over the eastern parts of Bangladesh agree with those of neighboring regions. Although the analysis of rainfall and extreme rainfall indices did not show any clear trend for the eastern region of Bangladesh as a whole, the local trend directions, magnitude and patterns identified for rainfall may provide useful information on the regional climate change. The association of rainfall and extreme rainfall trends with flood, drought, food supply and availability of water with respect to current and projected climate scenarios are some of the potential extensions and applications of this study.

\section{Compliance with ethical standards}

Conflict of interest On behalf of all authors, the corresponding author states that there is no conflict of interest.

\section{References}

1. Ahmed ASMS, Munim AA, Begum QN, Choudhury AM (1996) El Niño southern oscillation and rainfall variation over Bangladesh. Mausam 47(2):157-162 
2. Ahmed AU, Alam M (1999) Development of climate change scenarios with general circulation models. In: Huq S, Karim Z, Asaduzzaman M, Mahtab F (eds) Vulnerability and adaptation to climate change for Bangladesh. Kluwer Academic Publishers, Dordrecht, pp 125-143

3. Alexander LV, Zhang X, Peterson TC, Caesar J, Gleason B, Klein Tank AMG, Haylock M, Collins D, Trewin B, Rahimzadeh F, Tagipour A, Rupa Kumar K, Revadekar J, Griffiths G, Vincent L, Stephenson DB, Burn J, Aguilar E, Brunet M, Taylor M, New M, Zhai P, Rusticucci M, Vazquez-Aguirre JL (2006) Global observed changes in daily climate extremes of temperature and precipitation. J Geophys Res Atmos 111:D05109

4. Allen MR, Ingram WJ (2002) Constraints on future changes in climate and the hydrologic cycle. Nature 419:224-232

5. Ara I, Ostendorf B (2017) A review of food security and the potentials to develop spatially informed food policies in Bangladesh. Earth Syst Environ 1(2):19

6. Basher MA, Stiller-Reeve MA, Islam AS, Bremer S (2018) Assessing climatic trends of extreme rainfall indices over northeast Bangladesh. Theor Appl Climatol 134(1-2):441-452

7. Bates B, Kundzewicz Z, Wu S, Palutikof J (2008) Climate change and water. Technical Paper of the Intergovernmental Panel on Climate Change, IPCC Secretariat, Geneva

8. Bhuyan MDI, Islam MM, Bhuiyan MEK (2018) A trend analysis of temperature and rainfall to predict climate change for northwestern region of Bangladesh. Am J Clim Change 7:115-134

9. Chattopadhyay S, Edwards DR (2016) Long-term trend analysis of precipitation and air temperature for Kentucky, United States. Climate 4(1):1-10

10. Deshpande NR, Kothawaleb DR, Kulkarnic A (2016) Changes in climate extremes over major river basins of India. Int J Clim 36(14):4548-4559

11. Donat MG, Alexander LV, Yang H, Durre I, Vose R, Dunn RJH, Willett KM, Aguilar E, Brunet M, Caesar J, Hewitson B, Jack C, Klein Tank AMG, Kruger AC, Marengo J, Peterson TC, Renom M, Rojas CO, Rusticucci M, Salinger J, Elrayah AS, Sekele SS, Srivastava AK, Trewin B, Villarroel C, Vincent LA, Zhai P, Zhang X, Kitching $S$ (2013) Updated analyses of temperature and precipitation extreme indices since the beginning of the twentieth century: the HadEX2 dataset. J Geophys Res Atmos 118:2098-2118

12. Easterling DR, Meehl GA, Parmesan C, Changnon SA, Karl TR, Mearns LO (2000) Climate extremes: observations, modeling, and impacts. Science 289:2067-2074

13. Feidas H, Noulopoulou CH, Makrogiannis T, Bora-Senta E (2007) Trend analysis of precipitation time series in Greece and their relationship with circulation using surface and satellite data: 1955-2001. Theor Appl Climatol 87:155-177

14. Frich P, Alexander LV, Della-Marta PM, Gleason B, Haylock M, Tank AK, Peterson T (2002) Observed coherent changes in climatic extremes during the second half of the twentieth century. Clim Res 19(3):193-212

15. Gilbert RO (1987) Statistical methods for environmental pollution monitoring. Van Nostrand Reinhold, New York

16. Haylock MR, Peterson TC, Alves LM, Ambrizzi T, Anunciação YMT, Baez J, Barros VR, Berlato MA, Bidegain M, Coronel G, Corradi V, Garcia VJ, Grimm AM, Karoly D, Marengo JA, Marino MB, Moncunill DF, Nechet D, Quintana J, Rebello E, Rusticucci M, Santos JL, Trebejo I, Vincent LA (2006) Trends in total and extreme South American rainfall in 1960-2000 and links with sea surface temperature. J Clim 19(8):1490-1512

17. Hossain MN, Paul SK (2018) Vulnerability factors and effectiveness of disaster mitigation measures in the Bangladesh coast. Earth Syst Environ 2(1):55-65

18. Intergovernmental Panel on Climate Change (2007) Climate change 2007: impacts, adaptation and vulnerability. In: Parry ML, Canziani OF, Palutikof JP, van der Linden PJ, Hanson CE (eds) Contribution of working group II to the fourth assessment report of the Intergovernmental Panel on Climate Change. Cambridge University Press, Cambridge

19. IPCC (2014) Climate change 2014: IPCC fifth assessment synthesis report-summary for policymakers. An assessment of inter-governmental panel on climate change. Cambridge University Press, Cambridge

20. Islam MN (2009) Rainfall and temperature scenario for Bangladesh. Open Atmos Sci J 3:93-103

21. Jain SK, Kumar V (2012) Trend analysis of rainfall and temperature data for India. Curr Sci 102:37-49

22. Jain SK, Kumar V, Saharia M (2013) Analysis of rainfall and temperature trends in northeast India. Int J Climatol 33:968-978

23. Karmalkar AV, Bradley RS, Diaz HF (2011) Climate change in Central America and Mexico: regional climate model validation and climate change projections. Clim Dyn 37:605-629

24. Kendall MG (1975) Rank correlation methods. Griffin, London

25. Klein Tank AM, Peterson TC, Quadir DA, Dorji S, Zou X, Tang H, Santhosh K, Joshi UR, Jaswal AK, Kolli RK, Sikder AB, Deshpande NR, Revadekar JV, Yeleuova K, Vandasheva S, Faleyeva M, Gomboluudev P, Budhathoki KP, Hussain A, Afzaal M, Chandrapala L, Anvar H, Amanmurad D, Asanova VS, Jones PD, New MG, Spektorman T (2006) Changes in daily temperature and precipitation extremes in central and south Asia. J Geophys Res Atmos 111:D16

26. Kripalani RH, Inamdar S, Sontakke NA (1996) Rainfall variability over Bangladesh and Nepal: comparison and connections with features over India. Int J Clim 16(6):689-703

27. Liu B, Xu M, Henderson M, Qi Y (2005) Observed trends of precipitation amount, frequency, and intensity in China, 1960-2000. J Geophys Res Atmos 110:D8

28. Longobardi A, Villani P (2010) Trend analysis of annual and seasonal rainfall time series in the Mediterranean area. Int J Climatol 30(10):1538-1546

29. Mann HB (1945) Nonparametric tests against trend. Econometrica 13(3):245-259

30. Marengo JA, Jones R, Alvesa LM, Valverde MC (2009) Future change of temperature and precipitation extremes in South America as derived from the PRECIS regional climate modeling system. Int J Climatol 29(15):2241-2255

31. McCarthy JJ, Canziani OF, Leary NA, Dokken DJ, White KS (eds) (2001) Climate change 2001: impacts, adaptation and vulnerability. Cambridge University Press, Cambridge

32. Nashwan MS, Shahid S (2018) Spatial distribution of unidirectional trends in climate and weather extremes in Nile river basin. Theor Appl Climatol. https://doi.org/10.1007/s0070 4-018-2664-5

33. Panthi J, Dahal P, Shrestha ML, Aryal S, Nir KY, Pradhanang SM, Lakhankar T, Jha AK, Sharma M, Karki R (2015) Spatial and temporal variability of rainfall in the Gandaki River Basin of Nepal Himalaya. Climate 3:210-226

34. Rahimi M, Mohammadian N, Vanashi AR, Whan K (2018) Trends in indices of extreme temperature and precipitation in Iran over the period 1960-2014. Open J Ecol 8:396-415

35. Rahman MM, Ferdousi N (2012) Rainfall and temperature scenario for Bangladesh using $20 \mathrm{~km}$ mesh AGCM. Int J Clim Change Strateg Manag 4(1):66-80

36. Rahman MM, Rajib MA, Hassan MM, Iskander SM, Khondoker MTH, Rakib ZB, Ankur AK (2012) Application of RCM-based climate change indices in assessing future climate: part IIprecipitation concentration. World Environmental and Water Resources Congress, Albuquerque, pp 1787-1793

37. Rahman MR, Lateh H (2015) Climate change in Bangladesh: a spatio-temporal analysis and simulation of recent temperature and rainfall data using GIS and time series analysis model. Theor Appl Climatol 128(1-2):27-41 
38. Rajib MA, Rahman MM, Rakib ZB, Khondoker MTH, Iskander SM, Hassan MM, Mortuza MR (2012) Application of RCM-based climate change indices in assessing future climate: part I temperature extremes. World Environmental and Water Resources Congress, Albuquerque, pp 1779-1786

39. Rakib Z (2018) Characterization of climate change in Southwestern Bangladesh: trend analysis of temperature, humidity, heat index and rainfall. Clim Res 76(3):241-252

40. Rakib ZB (2013) Extreme temperature climatology and evaluation of heat index in Bangladesh during 1981-2010. J Pres. Uni 2(2):84-95

41. Sen PK (1968) Estimates of the regression coefficient based on Kendall's tau. J Am Stat Assoc 63(324):1379-1389

42. Shahid S (2009) Spatio-temporal variability of rainfall over Bangladesh during the time period 1969-2003. J Atmos Sci 45(3):375-389

43. Shahid S (2010) Rainfall variability and the trends of wet and dry periods in Bangladesh. Int J Climatol 30:2299-2313

44. Shahid S (2011) Trends in extreme rainfall events of Bangladesh. Theor Appl Climatol 104:489-499

45. Solomon S, Qin D, Manning M, Alley RB, Berntsen T, Bindoff NL, Chen Z, Chidthaisong A, Gregory JM, Hegerl GC, Heimann M, Hewitson B, Hoskins BJ, Joos F, Jouzel J, Kattsov V, Lohmann U, Matsuno T, Molina M, Nicholls N, Overpeck J, Raga G, Ramaswamy V, Ren J, Rusticucci M, Somerville R, Stocker TF, Whetton P, Wood RA, Wratt D (2007) Technical summary. In: Solomon S, Qin D, Manning M, Chen Z, Marquis M, Averyt KB, Tignor M, Miller $\mathrm{HL}$ (eds) Climate change 2007: the physical science basis. Contribution of working group I to the fourth assessment report of the Intergovernmental Panel on Climate Change. Cambridge University Press, Cambridge, pp 21-91

46. Trenberth KE (2011) Changes in precipitation with climate change. Clim Res 47:123-138

47. Vincent LA, Aguilar E, Saindou M, Hassane AF, Jumaux G, Roy $D$, Booneeady P, Virasami R, Randriamarolaza LYA, Faniriantsoa FR, Amelie V, Seeward H, Montfraix B (2011) Observed trends in indices of daily and extreme temperature and precipitation for the countries of the western Indian Ocean, 1961-2008. J Geophys Res Atmos 116:D10108
48. Vincent LA, Mekis E (2006) Changes in daily and extreme temperature and precipitation indices for Canada over the twentieth century. Atmos Ocean 44(2):177-193

49. Vincent LA, Peterson TC, Barros VR, Marino MB, Rusticucci M, Carrasco G, Ramirez E, Alves LM, Ambrizzi T, Berlato MA, Grimm AM, Marengo JA, Molion L, Moncunill DF, Rebello E, Anunciação YMT, Quintana J, Santos JL, Baez J, Coronel G, Garcia J, Trebejo I, Bidegain M, Haylock MR, Karoly D (2005) Observed trends in indices of daily temperature extremes in South America 1960-2000. J Clim 18(23):5011-5023

50. Wang XL (2008) Accounting for autocorrelation in detecting mean-shifts in climate data series using the penalized maximal t or F test. J Appl Meteor Climatol 47(9):2423-2444

51. Wang XL (2008) Penalized maximal $F$ test for detecting undocumented mean-shifts without trend-change. J Atmos Ocean. Technol 25(3):368-384

52. Wang XL, Feng Y (2013) RHtests_dlyPrcp user manual. Climate Research Division Atmospheric Science and Technology Directorate Science and Technology Branch, Environment Canada Toronto, ON

53. Wang $X L$, Wen $Q H, W u Y$ (2007) Penalized maximal $t$ test for detecting undocumented mean change in climate data series. J Appl Meteor Climatol 46(6):916-931

54. Yazid M, Humphries U (2015) Regional observed trends in daily rainfall indices of extremes over the Indochina Peninsula from 1960 to 2007. Climate 3(1):168-192

55. Zhang C, Wang Z, Zhou B, Li Y, Tang H, Xiang B (2018) Trends in autumn rain of West China from 1961 to 2014. Theor Appl Climatol 135(1-2):533-544

56. Zhang $X$, Alexander L, Hegerl GC, Jones P, Tank AK, Peterson TC, Trewin B, Zwiers FW (2011) Indices for monitoring changes in extremes based on daily temperature and precipitation data. WIREs Clim Change 2(6):851-870

Publisher's Note Springer Nature remains neutral with regard to jurisdictional claims in published maps and institutional affiliations. 